\title{
Optimal Investment Strategy for Solar PV Integration in Residential Buildings: A Case Study in The Philippines
}

\author{
Charmaine Samala Guno ${ }^{a}$, Casper Boongaling Agaton ${ }^{b, c^{*}}$, Resy Ordona Villanuevad, \\ Riza Ordona Villanueva ${ }^{\mathrm{e}}$
}

\author{
${ }^{a}$ College of Teacher Education, Mindoro State College of Agriculture and Technology, Calapan City, Philippines \\ ${ }^{b}$ Utrecht University School of Economics, Utrecht University, Utrecht, The Netherlands \\ ${ }^{c}$ Copernicus Institute of Sustainable Development, Utrecht University, Utrecht, The Netherlands \\ ${ }^{d}$ Senior High School Department, Ceriaco A. Abes Memorial National High School, Calapan City, Philippines \\ eEnglish Department, Oriental Mindoro National High School, Calapan City, Philippines
}

\begin{abstract}
In developing countries, particularly in rural areas, long periods of power outages are experienced as the electricity grid is technically or economically unfeasible. As solar photovoltaic (PV) is the most potential and suitable source of renewable energy for these areas, this paper analyzes the economic viability of its integration in different types of residential buildings. Applying real options approach under uncertainty in electricity prices, this study compares the attractiveness of adopting solar PV over continuing electricity from the grid focusing on various investment payment schemes including (i) full payment, (ii) distributed payment for 5 or 10 years without a down payment, and (iii) distributed payment for 5 or 10 years with $20 \%$ or $40 \%$ down payment. Applying the model with the case of the Philippines, the results with the full payment strategy obtain option values of USD 6888 for building type-I, USD 15349 for building type-II, USD 21204 for building type-III, USD 27870 for building type-IV, and USD 34251 for building type-V. These option values increase by $21.6 \%$ and $22.5 \%$ with distributed payment scheme to a 5 - or 10 -year period and increase by $5 \%$ and $13 \%$ for distributed payment with $40 \%$ and $20 \%$ down payment. These option values decrease with investments at later periods. Contrary to the conventional option valuation results of an optimal decision to wait, our findings show the otherwise as earlier investment reduces the risk of opportunity loss from delaying the adoption of solar PV. Among the payment schemes analyzed, the distribution of PV system cost in a 10-year installment period without down payment shows to be the most optimal investment strategy which may encourage lower-income and risk-averse consumers whose decision to adopt solar PV is affected by cost barriers, economic status, and household income. The study suggests the government, particularly in developing countries, to support the integration of own-use solar PV in buildings through incentives and subsidies, as well as financial institutions to offer more affordable terms of payment that encourages low to medium income households to adopt solar PV. Further, this will not only augment the energy deficiency in these countries but also support the global aspirations of reducing greenhouse gas emissions and its adverse effects through gradually shifting to renewable sources of energy.
\end{abstract}

Keywords: investment strategy; investment under uncertainty; real options; renewable energy; residential building; solar PV

Article History: Received: $3^{\text {rd }}$ Sept 2020; Revised: $13^{\text {th }}$ Oct 2020; Accepted: $20^{\text {th }}$ Oct 2020; Available online: $25^{\text {st }}$ Oct 2020

How to Cite This Article: Guno, C.S., Agaton, C.B., Villanueva, R.O and Villanueva, R.O. (2021). Optimal Investment Strategy for Solar PV Integration in Residential Buildings: A Case Study in The Philippines. Int. Journal of Renewable Energy Development, 10(1), 79-89.

https://doi.org/10.14710/ijred.2021.32657

\section{Introduction}

Buildings are responsible for over one-third of global final energy consumption and $28 \%$ of the total direct and indirect energy-related carbon dioxide $\left(\mathrm{CO}_{2}\right)$ emissions (International Energy Agency (IEA) 2020). Therefore, by transforming buildings into a more sustainable and energy-efficient, global energy demand and emissions can significantly be reduced. The integration of solar photovoltaic (PV) plays an important role in the development of more sustainable buildings and brings significant changes in power systems. According to IEA report (2019), the integration of solar PV systems on residential, commercial, and industrial buildings is taking off in the next five years accounting to $60 \%$ of the world's total renewable-based power capacity growth and transforming the way electricity is generated and consumed. Accelerated growth in the ability of consumers to generate own-use electricity offers new opportunities and risks for electricity providers and policymakers around the world (IEA 2019).

While most developing countries in the Asia-Pacific region have embraced solar energy, the Philippines is lagging in terms of investments and policy implementation (Deutsche Gesellschaft für Internationale Zusammenarbeit GmbH (GIZ) 2013). Currently, solar energy accounts for $1.2 \%$ of the country's total energy

\footnotetext{
* Corresponding author: c.b.agaton@uu.nl
} 
generation (Department of Energy (DOE) 2019) despite its geographic location advantage in the tropics and huge solar potential of about >1528 MW (International Renewable Energy Agency (IRENA) 2017). The government is aiming to tap this potential by awarding micro- to mini-grid solar projects and encouraging the adoption of own-use solar PV (Agaton and Karl 2018). With the falling costs of equipment and system installation (IEA 2019), as well as possible future savings from paying high electricity rate in the country (Enteria, Awbi and Yoshino 2015), PV systems are becoming more popular among consumers particularly in far-flung areas that are not connected to the grid. However, household owners are hesitant to invest in solar PV due to budget constraints, lack of information on system providers, skepticism, compatibility issues, difficulty in using all appliances at the same time, and availability in the local market (Agaton and Karl 2018). These give an impetus to conduct a study that analyzes the economic viability of integrating solar PV in residential buildings and suggest investment strategies making own-use solar PV systems more attractive than continuing electricity from the grid.

\subsection{Economic Valuation of Solar $P V$ Integration in Buildings}

Most economic valuation techniques used in previous studies are based on discounted cash flow such as the net present value (NPV), internal rate of return (IRR), payback period (PBP), profitability index (PI), and return on investments (ROI). The recent economic valuation includes DÁdamo et al. (2020) which proposed an economic model based on NPV and discounted PBP evaluate the economic viability of PV systems in public buildings. Tantisattayakul and Kanchanapiya (2017) evaluated the financial ROI of the solar rooftop system for the residential sector under Thailand's current Feed-inTariff (FiT) framework and proposed additional appropriate stimulus measures including appropriate FiT rate, personal income tax exemptions, carbon trading, and low-interest rate loans to encourage the investment for solar PV. D'Adamo (2018) analyzed the profitability of PV systems considering the implementation of subsidies based on the reduction of $\mathrm{CO}_{2}$ emissions from the energy produced using PV systems. Rodrigues, Chen and Morgado-Dias (2017) analyzed the profitability of PV systems in considering the solar radiation levels, selfconsumption savings, cash flows from injecting power into the grid, and local prices for installations. Allouhi (2020) introduced a new multi-objective optimization approach to optimize economically and environmentally the implementation of solar photovoltaic systems for selfconsumption using the levelized cost of electricity (LCOE) and the cumulative environmental benefit as two life-cycle conflicting objective functions. A more comprehensive work includes Ellabban and Alassi (2019) that proposed an Integrated Economic Adoption Model for distributed PV systems combining NPV, IRR, PBP, and PI with LCOE and Monte Carlo Analysis to assess different electricity retail tariff structures for the adoption of residential solar PV using the case of Australia.

\subsection{Real Options Valuation of Solar PV Integration in Buildings}

The traditional economic valuation methods, albeit very useful, do not capture some important characteristics of energy investments such as irreversibility in which the capital cost cannot be recovered after the investment is done; risks which contain uncertainties in future cashflow; and flexibility in making investment decisions (Agaton et al. 2019). The real options approach (ROA) overcomes these limitations as it combines risks and uncertainty with the flexibility of investment decisions as potential positive factors that provide added value to a project (Agaton et al. 2019). While most literatures apply ROA in a large-scale power generation, only a few studies use this method in evaluating own-use solar PV project for residential and commercial buildings. For instance, Moon and Baran (2018) proposed a ROA model to determine the optimal investment timing for residential PV considering the uncertainty in PV cost and a resident's option to defer investment using the case studies for the United States (US), Germany, Japan, and Korea. The study applied dynamic programming considering the uncertainty in PV system cost described using geometric Brownian motion (GBM), compared the study to the net present value (NPV) method, and found that PV system investment could be additionally delayed by $5.76-11.01$ years. Torani, Rausser and Zilberman (2016) developed a ROA stochastic dynamic programming model for the adoption of solar PV in the residential and commercial buildings in the US. The model evaluated the threshold and timing of the consumer's optimal investment decision given the uncertainties in electricity prices and cost of the solar panel described using GBM, and obtained a cumulative likelihood and timing of substitution amongst energy resources and towards solar under plausible rates of electricity prices, technological change, subsidies and carbon taxes. In another study in the US, Gahrooei et al. (2016) proposed a ROA framework based on dynamic programming to assist decision-makers in finding the optimal timing of investment and the size of solar panels when implementing a residential PV system. The study described the uncertainty in electricity prices using GBM, technology learning for solar panel cost, and uncertainty quantification repository for building performance. The ROA model is applied in a reference residential house at different investment scenarios and revealed a preferred option to delay the investment. Meanwhile, Penizzotto, Pringles and Olsina (2019) developed a real options model based on stochastic simulation, linear regression, and backward dynamic programming to appraise investments in PV generation systems to be installed on the rooftop of a government building in Argentina. The study considered uncertainties upon declining investment costs described by a Poisson process as well as fluctuating electricity tariffs following GBM and found that these uncertainties give substantial value to defer the investment.

\subsection{Literature Gap, Contribution, and Research Objectives}

The real options literatures focus on the timing of investment in PV systems and various investment drivers such as technology cost, electricity price, government subsidy, and carbon tax applied to the cases of developed countries. Hence, we identify a gap in the application of ROA on the adoption of solar PV focusing on investment payment schemes which are exceptionally important to households from low- to middle-income countries which consider the PV system as a capital-intensive project. We aim to bridge this gap by proposing a general ROA framework for analyzing the adoption of solar PV in 
residential buildings (RB) under various payment strategies in the context of developing countries.

Specifically, we evaluate the option values and the optimal timing of switching electricity source from the grid to own-use solar PV at different RB types under uncertainty in electricity prices; and identify the optimal investment strategy among various payment schemes including (i) full payment, (ii) distributed payment for 5 or 10 years without a down payment, and (iii) distributed payment for 5 or 10 years with $20 \%$ or $40 \%$ down payment. These payment schemes are offered in the case country investigated with the solar PV company's aim of providing PV system costs affordable to consumers. We apply the proposed model using the Philippines as a case study with the following motivations: (a) it is a developing country with a huge potential to tap solar energy due to its geographical location; (b) the country is archipelagic and $\mathrm{RB}$ in some rural areas are not connected to the national grid; (c) high capital cost for PV system; (d) high electricity prices; and (e) local solar PV system providers offer various payment schemes that cater various economic status of the consumers. We finally aim to recommend policies to support the adoption of a more sustainable source of energy in the context of developing countries.

\section{Materials and Methods}

\subsection{Real Option Model for Solar PV Payment Schemes}

The real option model in this study takes the perspective of an investor, a household, or a business owner, who has a decision-making period $\mathrm{T}_{\mathrm{D}}$ to shift electricity source from the grid to own-use solar PV. Within this period, he has the option to invest immediately or postpone the investment until the terminal period $t=T_{D}$. The switching of electricity sources gives the investor an energy-saving value of $\mathrm{V}_{\mathrm{sav}, \mathrm{t}}$ calculated as the product electricity retail price and the cumulative amount of solar energy consumed (Ren, Mitchell and Mo 2020; Zeng and Chen 2020) described here as the savings from using electricity from the grid as shown in Eq. 1.

$$
\mathrm{V}_{\mathrm{sav}, \mathrm{t}}=\mathrm{P}_{\text {elec,t }} \mathrm{Q}
$$

Investment for the PV system and its installation incurs a cost of $\mathrm{C}$ which can be given in (a) full payment $\mathrm{I}_{\tau}$; (b) monthly installment $\mathrm{I}_{\text {ins }}$ with down payment $\mathrm{I}_{\mathrm{dp}}$; and (c) monthly installment without down payment represented by

$$
\left.\begin{array}{cc}
I_{d p, \tau}+\sum_{t=\tau}^{I_{\tau}} \rho^{t} I_{i n s, t} & \text { installment with downpayment } \\
\sum_{t=\tau}^{n} \rho^{t} I_{\text {ins,t }} & \text { installment without downpayment }
\end{array}\right\}
$$

with a discount factor $\rho^{\mathrm{t}}=\frac{1}{(1+\delta)^{\mathrm{t}}}$ at discount rate $\delta$.

The NPV of investment in solar PV is represented in Eq. 2 (Adebayo and Koçyiğit 2020; Krungkaew et al. 2020) where $\mathrm{T}_{\text {solar }}$ is the effective lifetime operation of solar PV

\footnotetext{
* We initially considered Mean Reversion model to describe the stochastic prices of electricity in line with previous studies (e.g. Borovkova and Schmeck 2017; Andreis et al. 2020). However, the Augmented Dickey-Fuller unit root
}

system and $\mathrm{C}$ is the investment cost including the PV system, installation, maintenance, and warranty.

$$
\mathrm{NPV}_{\text {solar }}=\sum_{\mathrm{t}=\tau}^{\mathrm{T}_{\text {solar }}} \rho^{\mathrm{t}} \mathrm{V}_{\text {sav }, \mathrm{t}}-\mathrm{C}_{\mathrm{t}}
$$

We assume that the electricity price, $\mathrm{P}_{\mathrm{elec}}$, is stochastic and follows GBM* (Andreis et al. 2020; Ioannou, Angus and Brennan 2018; Borovkova and Schmeck 2017) as described in Eq. 3

$$
\mathrm{dP}_{\text {elec }} / \mathrm{P}_{\text {elec }}=\alpha \mathrm{dt}+\sigma \mathrm{dz}
$$

GBM is a Markovian stochastic process in which the logarithm of the randomly varying quantity follows a Brownian motion (also called a Wiener process) with drift. It is a process of forecasting future prices based on the last observed record (Abensur, Moreira and de Faria 2020). From the historical prices, the drift $\alpha$ and standard deviation $\sigma$ parameters are obtained representing the mean and volatility of the price process, $d t$ is the infinitesimal time increment, and $\mathrm{dz}$ is the increment of the Wiener process equal to $\varepsilon_{t} \sqrt{d t}$ such that $\varepsilon_{t} \sim N(0,1)$. The future price of electricity, $\mathrm{P}_{\text {elec,t}}$, at period $\mathrm{t}$ depends on its previous price, the drift, and variance from the historical electricity price trend (Tian et al. 2017; Agaton and Karl 2018) as shown in Eq. 4.

$$
\mathrm{P}_{\text {elec }, \mathrm{t}}=\mathrm{P}_{\text {elec, } \mathrm{t}-1}+\alpha \mathrm{P}_{\text {elec, } \mathrm{t}-1}+\sigma \mathrm{P}_{\text {elec,t }-1} \varepsilon_{\mathrm{t}-1}
$$

From Eq. 4, we generate the price paths from the current electricity price and incorporate these in Eq. 3. Using Monte Carlo simulations, we estimate the expected net present value $\mathbb{E}[\mathrm{NPV}]$ of adopting solar PV as described in Eq. 5 (Tian et al. 2017; Agaton et al. 2020). This process repeats the calculations in multiple number of times considering the stochastic prices of electricity and calculating the average NPV from all the iterations.

$$
\begin{aligned}
\mathbb{E}\left\{\mathrm{NPV}_{\text {solar,j }} \mid \mathrm{P}_{\text {elec }, 0}\right\} & \approx \frac{1}{\mathrm{~J}} \sum_{1}^{\mathrm{J}} \mathrm{NPV}_{\text {solar }, \mathrm{j}} \\
& \approx \mathbb{E}\left\{\mathrm{NPV}_{\text {solar }} \mid \mathrm{P}_{\text {elec }, 0}\right\}
\end{aligned}
$$

The investor's problem is to maximize the value of adopting solar PV or continuing the electricity from the grid given in Eq. 6 (Zhang et al. 2019; Agaton et al. 2020).

$$
\mathrm{OV}_{\mathrm{t}}=\max \left\{\left[\mathbb{E}\left\{N P V_{\text {solar }}\right\}, \mathbb{E}\left\{\sum_{0 \leq \mathrm{t} \leq \tau} \rho^{\mathrm{t}} \mathrm{V}_{\text {sav }, \mathrm{t}}\right\}\right] \mid \mathrm{P}_{\text {elec }, \mathrm{t}}\right\}
$$

We define the option value $\mathrm{OV}_{\mathrm{t}}$ as the maximized value of either investing in a solar PV system with $\mathbb{E}\left\{\mathrm{NPV}_{\text {solar }}\right\}$ or continuing the use of electricity from the grid $\mathbb{E}\left\{\sum_{0 \leq t \leq \tau} \rho^{t} V_{\text {sav, } t}\right\}$ considering the stochastic price of electricity $\mathrm{P}_{\text {elec,t }}$ at time t. Applying dynamic optimization, option values are calculated from the terminal period $t=$ $\mathrm{T}_{\mathrm{D}}$ to $\mathrm{t}=0$ using backward induction. The optimal timing of investment $\tau^{*}$ is characterized by the minimum period where adopting solar PV is maximized as shown in Eq. 7.

test for the time series of prices indicated that electricity prices in the case country follow Geometric Brownian motion. 


$$
\mathrm{T}^{*}=\min \left\{\tau \mid O V_{\mathrm{t}}=O \mathrm{VV}_{\mathrm{t}-1}\right\}
$$

Given the $\tau^{*}$, optimal investment strategy is characterized by a decision to invest immediately or to postpone the investment into a more favorable period as shown below.

$$
\left.\begin{array}{lc}
\mathrm{OV}_{\tau^{*}}\left(\mathrm{P}_{\text {elec }, \mathrm{t}}\right) \leq \mathrm{OV}_{0}\left(\mathrm{P}_{\text {elec }, 0}\right) & \text { invest } \\
\mathrm{OV}_{\tau^{*}}\left(\mathrm{P}_{\text {elec }, \mathrm{t}}\right)>0 \mathrm{OV}_{0}\left(\mathrm{P}_{\text {elec }, 0}\right) & \text { delay, postpone }
\end{array}\right\}
$$

\subsection{Data and Parameter Estimates}

We apply the proposed ROA model to residential buildings using the case of the Philippines. To estimate the parameters for the optimization problem, we use the data from DOE, Manila Electric Company (Meralco), and Solar Philippines.

For electricity prices, a 10-year period of average annual prices from 2010 to 2019 is used to run the Augmented Dickey-Fuller (ADF) unit root test for the stochastic process. The result in Table 1 shows that the null hypothesis that $\mathrm{P}_{\text {elec }}$ has a unit root at all significant levels cannot be rejected and therefore, $\mathrm{P}_{\text {elec }}$ follows GBM with drift and volatility $\alpha=0.04053$ and $\sigma=0.03033$. We use these parameters to generate stochastic prices of electricity from the current $\mathrm{P}_{\text {elec,t }}=\mathrm{USD} 10.6 \mathrm{c} / \mathrm{kWh}$.
All investment-related parameters are the actual data obtained from the Solar Philippines, the largest solar PV system provider in the case country. The PV system provider offers various payment schemes for different building types as shown in Table 2 . The building types are grouped according to the average yearly electricity consumption from less than $6 \mathrm{MWh}$ to $30 \mathrm{MWh}$ at $6 \mathrm{MWh}$ interval, while solar panels installed for each building type are 2, 5, 7, 14, and 28.* Investment schemes include full payment, or monthly installment in 5 or 10 years, with or without a down payment. ${ }^{\dagger}$ With the installment scheme, the monthly payment is reduced by $25 \%$ with a $20 \%$ down payment and a $50 \%$ reduction with a $40 \%$ down payment. The investment cash flow is discounted at a $7.5 \%$ risk-free interest rate. The project runs for a 25 -year lifetime of full off-grid operation with no sell-back option. We set the optimization period to $T_{D}=25$ years to make the investment decision. Other assumptions include solar PV generates electricity at an annual average of Q throughout its effective lifetime; the investment cost and installment payments are constant for the whole decision period; there are no additional costs for annual maintenance as this will be covered by the warranty from the provider; and the average annual consumption of electricity is assumed to be constant for all types of RB analyzed.

Table 1

ADF Unit Root Test for Electricity Prices

\begin{tabular}{ccccc}
\hline Dickey-Fuller test for unit root & \multicolumn{3}{c}{ Number of obs. $=$} & 10 \\
& $\begin{array}{c}\text { Interpolated Dickey-Fuller } \\
\text { Test }\end{array}$ & $\begin{array}{c}\text { 1\% Critical } \\
\text { Statistic }\end{array}$ & $\begin{array}{c}\text { Volue Critical } \\
\text { Valu }\end{array}$ & $\begin{array}{c}10 \% \text { Critical } \\
\text { Value }\end{array}$ \\
\hline $\mathrm{Z}(\mathrm{t})$ & -1.508 & -4.380 & -3.600 & -3.240 \\
MacKinnon approximate p-value for $\mathrm{Z}(\mathrm{t})=$ & & & & 0.8264 \\
\hline
\end{tabular}

Table 2

\begin{tabular}{cccccc} 
Investment schemes at different types of RB & \multicolumn{5}{l}{} \\
Building Type & $\begin{array}{c}\text { annual electricity } \\
\text { consumption } \\
\text { (MWh) }\end{array}$ & \# of panels & $\begin{array}{c}\text { full payment } \\
\text { (USD) }\end{array}$ & $\begin{array}{c}5 \text {-year } \\
\text { installment } \\
\text { (USD/mo) }\end{array}$ & $\begin{array}{c}\text { 10-year } \\
\text { installment } \\
\text { (USD/mo) }\end{array}$ \\
\hline I & below 6 & 5 & 2790 & 62.16 & 36.64 \\
II & $6-11.9$ & 7 & 3880 & 86.37 & 55.62 \\
III & $12-17.9$ & 14 & 7590 & 168.81 & 108.83 \\
IV & $18-23.9$ & 21 & 10860 & 241.66 & 155.94 \\
V & $24-30$ & 28 & 14350 & 319.30 & 205.89 \\
\hline
\end{tabular}

Data Source: Solar Philippines (accessed on 21 March 2020)

\footnotetext{
* The solar PV provider offers two more options which include 35- and 42-panel installations. However, these options are more applicable to larger commercial establishments which are beyond the scope of the study focusing on small to medium-type residential buildings.
}

† The solar PV provider gives another investment option to pay according to the electricity consumption of residential building. However, we did not include it in this study as it would not fit in the proposed ROA model.

\# While the sell-back option is available in most developing countries, this option is not yet operational at the household level of the selected case country. 


\section{Results}

\subsection{Baseline Result}

The option valuation result in the baseline scenario (full payment) for adopting solar PV is illustrated in Fig. 1. The colored curves describe the option values for each residential building type according to annual average electricity consumption as outlined in Table 2 . Each point on the curve indicates the maximized value of either adopting solar PV or continuing electricity from the grid for every investment period and each type of building.

Fig. 1 illustrates the optimization results for onetime investment in which an investor pays the total PV system cost including the installation, maintenance, and 10-year warranty. The result shows that at $\mathrm{t}=0$, the option values are USD 6888 for RB-I, USD 15349 for RBII, USD 21204 for RB-III, USD 27870 for RB-IV, and USD 34251 for RB-V. Among the building types analyzed, we identify that $\mathrm{RB}-\mathrm{V}$ with the highest electricity consumption obtains the highest option value. This is due to economies of scale where the cost of investing in the project decreases with an increasing number of solar panels installed and at the same time increases the energy-saving value (De Schepper, Passel and Lizin 2015; Mehta et al. 2019). Meanwhile, we observe that the option curves slope downwards which indicate a decline in the value of an investment over time. With RB-I for instance, the option value decreases to USD 5781 at $t=5$, USD 4494 at $\mathrm{t}=10$, USD 3060 at $\mathrm{t}=15$, USD 1559 at $\mathrm{t}=20$, and USD -208 at $t=25$. In the case of RB-V, the option value decreases to USD 28969 at $\mathrm{t}=5$, USD 22,650 at $\mathrm{t}=10$, USD 15710 at $\mathrm{t}=15$, USD 7556 at $\mathrm{t}=20$, and USD -87 at $t=25$. This is because our net present value is based on the energy savings value minus the cost of solar PV system. Therefore, the longer the waiting period, the lower the energy savings from generating own-use electricity. This is also observed on the negative option values at $t=$ 25 which indicate losses from delaying the investment. These results imply a more optimal decision to invest immediately in solar PV as delaying the adoption of ownuse solar PV incurs losses from paying electricity from the grid.

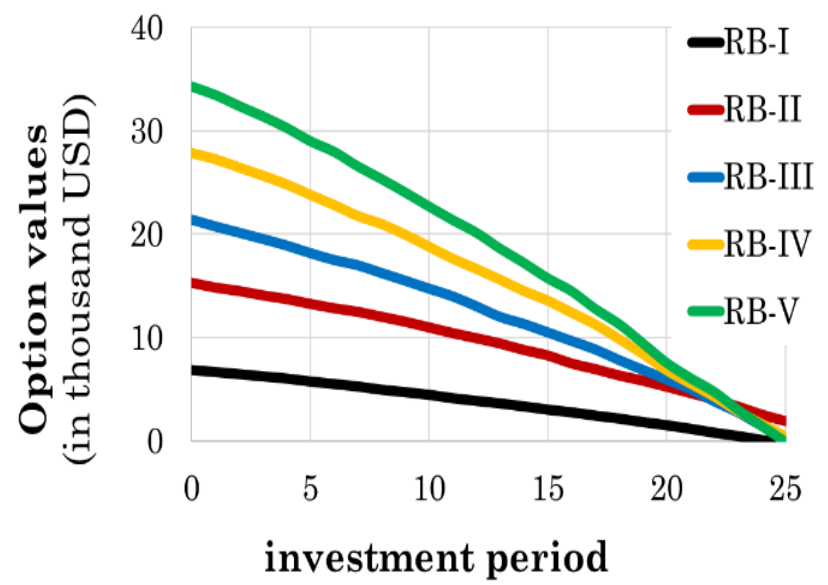

Fig. 1 Option values for solar PV investment for different types of RB types.
The delay of the investment may cause losses, if, e.g. investment expenditures or operating costs are expected to increase significantly in future periods (Schiel et al. 2020). Considering prosumers that invest in a larger PV system compared with that needed for self-consumption, delaying investment leads to the loss of the opportunity to sell the excess energy in the market (Bertolini, D'Alpaos $\&$ Moretto 2018).

\subsection{Payment Schemes}

In this scenario, we describe an investment scheme where the investor has the option to pay in full or pay a monthly amortization in 5 or 10 years. If the investor opts to pay monthly, he has the option to pay an initial $20 \%$ or $40 \%$ down payment reducing the monthly rates by $25 \%$ or $50 \%$ from the rate without an initial down payment. Additionally, the investor may also opt to pay the solar PV system cost on monthly basis without any down payment at all.

Figure 2 compares the option values of solar PV project for RB-V with full payment and 5-year and 10-year instalment schemes without down payment. The result shows a large difference between the option values of investment with full payment and investments payed in an instalment basis. Compared with the result in Fig. 1, the option value for $\mathrm{RB}-\mathrm{V}$ at $\mathrm{t}=0$ increases by $21.6 \%$ and $22.5 \%$ from USD 34251 for full payment investment, to USD 41645 and USD 41947 for 5-year and 10-year instalments without an initial down payment. Note that the findings for other RB types obtain the same increasing results for option values. With a 10-year instalment payment, for instance, the option values increase to USD 8335 for RB-I, USD 16656 for RB-II, USD 25021 for RBIII, and USD 33269 for RB-IV. These results indicate a better option to regularly pay a monthly amortization for a period of 5 or 10 years as the discounted present value of payment decreases over time. This scheme offers more benefits to the RB owners to pay the investment at a lower cost spread over a certain period. Further, this result gives more opportunities for RB owners to adopt solar PV as the monthly payment will only be $5-10 \%$ higher than the electricity bill payment.

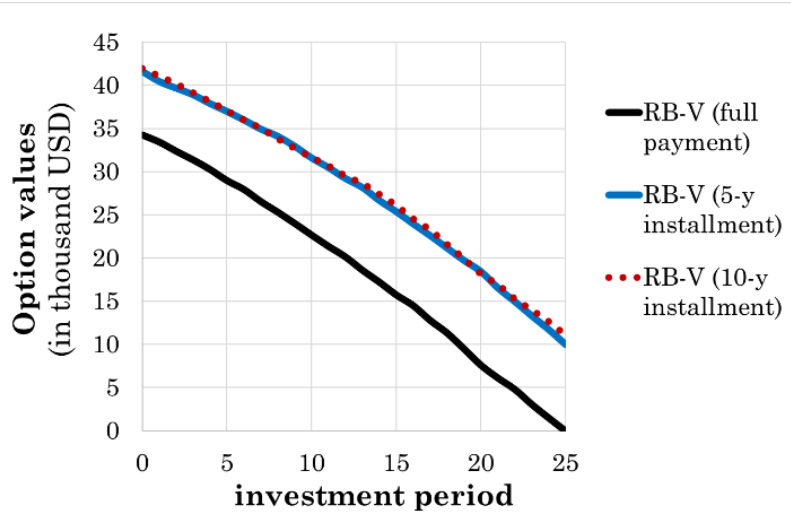

Fig. 2 Option Values of solar PV investments for RB-V at various installment schemes: full payment, and 5-y and 10-y installments without a down payment.*

\footnotetext{
* The results are robust with different RB types and down payment schemes.
} 


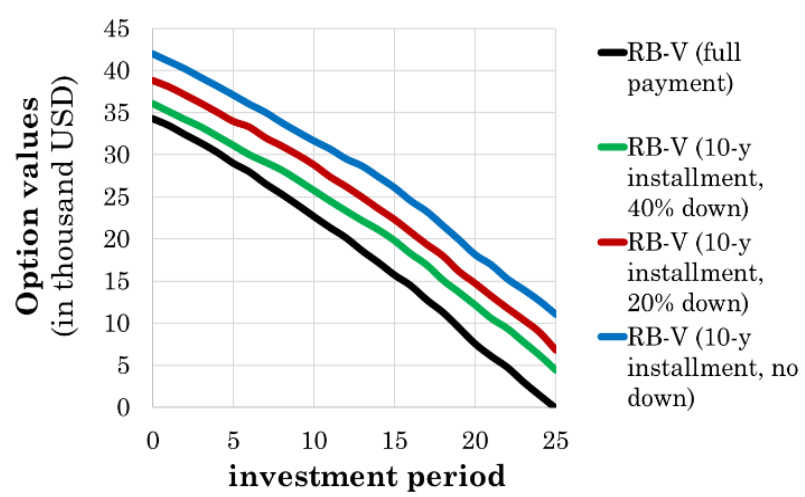

Fig. 3 Option values of solar PV investments for RB-V at various down payment schemes: full payment; $10 \mathrm{y}$ installment at $40 \%$ down payment; $10 \mathrm{y}$ installment at $20 \%$ down payment; and $10 \mathrm{y}$ installment without down payment.

Another investment scheme is to pay an initial down payment with reduced monthly amortization as shown in Figure 3. The result shows that investment without initial payment has the highest option values followed by $20 \%$ down payment, $40 \%$ down payment, and full payment. Take for instance the option values at $t=0$ for $R B-V$ with USD 34251 for full payment. The option value increases by $5 \%$ to USD 36088 for $40 \%$ down payment, $13 \%$ to USD 38816 for $20 \%$ down payment, and $22 \%$ to USD 41947 for no down payment with only monthly amortization for 10 years. Note that similar increasing option value results are obtained from other RB types analyzed. This suggests an optimal option to invest in a solar PV project by paying a fixed monthly rent for a given number of years without down payment. This result may encourage lower-income and risk-averse $\mathrm{RB}$ owners as cost barriers, economic status, and income affect their decision to adopt solar PV (Pode 2013; Guta 2018; Palm 2018). Further, the option values for investment without down payment for RB-V are USD 37007 for $\mathrm{t}=5$, USD 31621 for $\mathrm{t}=10$, USD 25394 for $t=15$, USD 18446 for $t=20$, and USD 9995 for $t=25$. The downward sloping of the option curve supports the previous claim of an optimal decision to invest earlier than delaying the adoption of solar PV.

\subsection{Electricity Price Volatility Scenario}

In this scenario, we describe how the uncertainty in electricity prices affects investment decisions to adopt solar PV. We use three various uncertainty levels including (a) base value from the time series of electricity prices described in section 2.2.a with $\sigma=0.03033$; (b) lower volatility which describes a more deterministic price of electricity at $\sigma=0.01$; and (c) higher volatility which indicates more variation from the trend in electricity prices at $\sigma=0.1$.

Figure 4 shows the option values for $R B-V$ for investment with full system cost payment at various uncertainty levels in electricity prices. The result shows an average $10 \%$ higher and more stable option value curve at low price volatility with USD 43599 at $t=0$, USD 37389 at $\mathrm{t}=5$, USD 29885 at $\mathrm{t}=10$, USD 21468 at $\mathrm{t}=15$, USD 10731 at $\mathrm{t}=20$, and USD 13 at $\mathrm{t}=25$.

* The results are robust with different RB types and installment schemes.

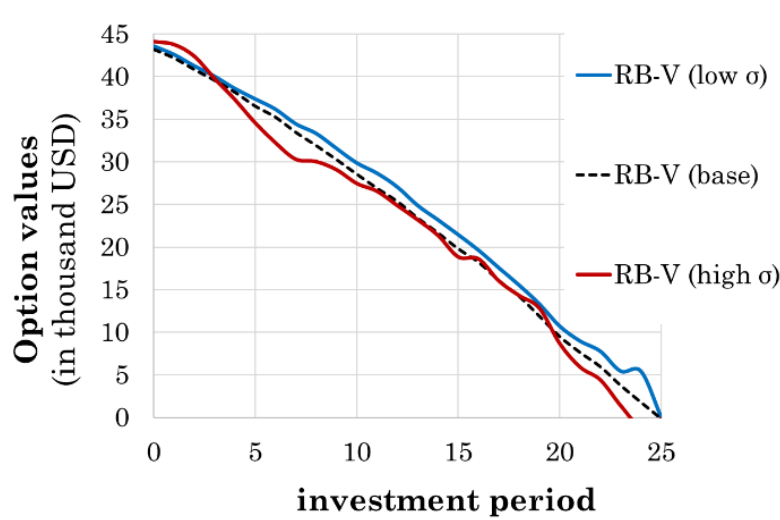

Fig. 4 Sensitivity of OV at various volatility of electricity prices: low $\sigma=$ low uncertainty and high $\sigma=$ high uncertainty.$^{\dagger}$

Results show that lower price volatility increases the option values at different investment periods. These results suggest a better decision to adopt solar PV earlier at a more deterministic trend in electricity retail price to avoid possible losses from investment risks (Gazheli and van den Bergh 2018). On the other hand, higher electricity volatility results in a fluctuating curve and an average of $6 \%$ lower option values with USD 44149 at $\mathrm{t}=$ 0 (higher than baseline), USD 34610 at $\mathrm{t}=5$ (lower), USD 27507 at $\mathrm{t}=10$ (lower), USD 18877 at $\mathrm{t}=15$ (higher), USD 8692 at $\mathrm{t}=20$ (lower), and USD -150 at $\mathrm{t}=25$ (lower). When prices of electricity are more volatile in the market, it is better to wait and delay the investment to avoid losses from investment risks. This is because project investors are risk-averse that they only consider a riskier project if they expect receiving higher returns to compensate for the risks (Agaton 2018). With higher uncertainty over future cash flows, the project's NPV and option value decrease, and therefore less attractive to investors (Agaton 2018). Further, it can be observed that the option values for higher electricity price volatility at the later periods are negative which indicates losses. The result describes the robustness of previous implications to adopt own-use solar PV to avoid opportunity losses from postponing the investment.

\section{Discussion}

\subsection{Summary of Findings and Relation to Prior Studies}

In this research, we develop an investment framework for integrating solar PV in residential buildings in the context of developing countries. Using ROA under uncertainty in electricity prices, we compare various investment strategies for different RB types. Our estimation results highlight two key findings: (a) a more optimal strategy to invest immediately in solar PV project than continuing electricity from the grid and (b) investment with 10 years installment without a down payment as the optimal strategy among the investment schemes analyzed. Contrary with ROA results from previous studies that waiting is a better option (Moon and Baran 2018; Gahrooei et al. 2016; Cheng et al. 2017; Penizzotto, Pringles and Olsina 2019), our results show differently with a more optimal decision to invest earlier in solar PV. One reason for this is the real options model used in previous studies

† The results are robust with different RB types, down payment schemes, and installment schemes. 
(e.g. Moon and Baran 2018; Penizzotto, Pringles and Olsina 2019) with the revenues based on the energy savings from the difference between energy generated from solar PV and own consumption. Given the uncertainties in prices, the option value increases with timing resulting in a more optimal decision to delay. In our study, the revenues are based on the savings from paying electricity from the grid assuming a self-sufficient own-use solar PV system. With this model, the option value decreases with time due to the losses incurred from paying electricity from the grid while waiting to invest. Therefore, the longer the waiting period, the higher the losses, and the lower the option value. These welfare losses are aggravated by high electricity prices in the Philippines. Compared with neighboring Asian developing countries, the Philippines has relatively higher electricity prices due to the country's dependence on imported fossil fuels, no government subsidy on electricity generation, fully costreflective, monopolized, and heavily taxed across the supply chain (Agaton et al. 2020). With higher electricity rates from fossil fuels, investment in renewable energy technologies, particularly the own-use solar PV, becomes more competitive (Lin and Chen 2019).

Among the investment schemes analyzed, we find that monthly installment without down payment has the highest option value for all RB types analyzed. This suggests investors adopt solar PV even without having an initial capital for the system and installation cost, so long as he can pay the monthly amortization dues spread within a 5- or 10-year installment period. This result is contrary to a previous study (Zhang et al. 2015) that buyout or full payment of solar heating system is considered a better investment method with higher NPV, IRR, and the shortest payback period in selected European (EU) countries. While both studies consider comparable discount rates (8\%) and constant payments for buying solar systems by installment, the PV system provider in the Philippines offers a lower interest rate of $5.7 \%$ (compared with $8 \%$ for selected EU countries). Financing at lower interest rates significantly improves the economics of investment in residential solar PV (Hagerman, Jaramillo and Morgan 2016). In another study, Khan et al. 2019 found that $60 \%$ of the users of the solar home system prefer installment payment financed through microcredit. This flexible financing scheme may increase the market share of the solar PV system, reach a greater number of households and increase their acceptance of the PV system to uplift the living standard in remote and underserved communities (Pode 2013). Hence, our result is highly relevant to households from developing countries who lack the capital to finance the solar PV system. This further supports previous claims that easy payment and installment schemes address the gap between high upfront costs for solar PV systems and low paying capacity of rural residents (Purohit, Purohit and Shekhar 2013; Yadav, Heynen and Palit 2019).

\subsection{Implications of the Study}

In addition to financial profitability, integration of solar $\mathrm{PV}$ in RB provides environmental, technological, and social implications. Along with accelerated energy efficiency measures, deeper electrification and the deployment of more renewables will significantly reduce the GHG emissions (Jäger-Waldau et al. 2020). In the case of the Philippines, the adoption of own-use solar PV reduces emissions with a factor of $0.56 \mathrm{~kg} \mathrm{CO} 2 \mathrm{eq} / \mathrm{kWh}$ electricity consumed from the grid (Agaton, Collera and Guno 2020). This implies a 3.97 tonCO $\mathrm{CO}_{2} /$ year reduction for RB-I and up to 18.52 ton CO2/year reduction for RB-V. The large deployment of solar PV not only reduces the total GHG emissions from the energy sector but also decrease the dependence on fossil fuels for electricity generation. On the other hand, it should be noted that this emission factor is still larger compared with those in the literature from other countries as the energy generation mix in the Philippines is dominated by coal and natural gas, which have high GHG emissions (Agaton, Collera and Guno 2020). The use of a dynamic grid emission factor will lead to a more rigorous quantification of the environmental benefits of the adoption of solar PV especially from an LCA perspective (Allouhi 2020).

While the adoption of solar PV has an advantage to the case country due to its geographic location, the energy yield from PV systems can still be maximized. Buildingintegrated PV systems should consider the orientation, the angle of inclination, the technology of the modules, and the latitude of the PV installation as the amount of the energy produced relates to the shape of the building and is often greater than the optimum for a given geographical situation (Stoyanov et al. 2020). A careful installation of PV systems represents a solution to reduce the electricity from the utility grid (Spertino et al. 2015). Another is to integrate battery systems and load control technologies that can temporarily shift PV output, an approach referred to as "solar plus". Large-scale solar plus deployment provides potential system benefits such as the value of energy, avoided network losses, avoided emissions, deferred network augmentation investments, and grid reliability which are unavailable through standalone PV systems (O'Shaughnessy et al. 2018).

Meanwhile, the financial valuation in this study results in optimal investment payment schemes for PV systems that favour the income-poor households. However, there are behavioral barriers that are more important for the energy-poor which can be categorized into internal barriers (preferences and predictable rational behavior, e.g. demographics, dwelling ownership, knowledge on technology) and external barriers (barriers that are independent of the decision-maker and depend on the institutional environment, e.g. building structure, market, regulatory policy) (Streimikiene et al. 2020; Stankuniene, Streimikiene \& Kyriakopoulos 2020). To increase the adoption of solar PV, these behavioral barriers should be considered such as promoting responsible behavior patterns and discouraging environmentally harmful and wasteful energy consumption and, at the same time, reducing income inequalities on energy consumption. (Streimikiene et al. 2020). Further, other social benefits of large-scale solar PV deployment should be promoted. These include the development of the solar manufacturing industry that creates jobs along the value chain as well as the health and environmental benefits of using cleaner and more sustainable sources of energy (Kabir, Kim, \& Szulejko 2017; Jäger-Waldau et al. 2020).

\subsection{Limitations and Future Research}

To develop a ROA framework for solar PV investment decisions, we made several simplifying assumptions leading to various limitations in the analyses. First, we 
assume that the electricity prices are stochastic and follow GBM with positive drift. This indicates an increasing trend in electricity prices in the long run. We acknowledge that the recent developments in renewable energy infrastructure projects and the widespread adoption of residential solar PV may eventually reduce the price of electricity in the future (Agaton et al. 2019). This trend in electricity prices should be accounted for. Moreover, different models to describe stochastic prices of electricity, such as mean-reverting and jump-diffusion, mean reversion process, and Autoregressive Integrated Moving average could also be used for further comparison of results using GBM (Ioannou, Angus and Brennan 2018; Borovkova and Schmeck 2017). We also assume the constant solar PV system costs throughout the decisionmaking period. We based this assumption on the solar PV system provider in our case country which offers fixed system costs and installment payments for 5- or 10-year period. However, capital cost for solar PV is expected to decrease in the future due to the learning curve effect, reduction of the cost for the PV raw materials, price competition for PV market, renewable energy policy spillover, and research and development (Trapey et al. 2016; Kavlak, McNerney and Trancik 2018; Matsuo 2019). This decrease in system cost should also be accounted for the ROA model.

In this study, we apply ROA under uncertainty in electricity prices and analyze the sensitivity of the results with respect to various volatilities of prices. We acknowledge that various uncertainties affect solar PV investment decisions not covered in this study. These include the increasing demand for cleaner sources of electricity; technological maturity in storage and market competition that may lower the investment cost; and government policies such as income tax exemption, subsidy for using clean energy, or carbon tax for using electricity generated from fossil fuels (Tantisattayakul and Kanchanapiya 2017; DÁdamo 2018; Zhang, Zhou and Zhou 2016). The country's long-term energy program aims to increase the renewable energy capacity to $60 \%$ of the total energy mix by developing localized renewable sources including wind, solar, geothermal, and hydropower (Agaton 2018). Given the country's geographic location advantage and the potential for generating electricity from solar (IRENA 2017), the solar energy is expected to increase from the current $1.2 \%$ of $23 \mathrm{GW}$ to at least $3.5 \%$ of $43 \mathrm{GW}$ capacity by 2040 . The increased demand for renewables creates more competition in the market resulting to a more mature technology and lower system cost (Nemet et al. 2020; Do et al. 2020). The proposed ROA could be extended by incorporating these uncertainties to further capture investment decisions relevant to market and climate change policy.

The evaluation of adopting solar PV for buildings in this study focus on financial analysis. While the findings provide a good investment decision support for low- to middle-income consumers, providing information on the environmental benefits of using solar PV may also encourage environment-conscious consumers to shift electricity sources. Recent studies show that the use of the solar system will avoid the emission of large quantities of pollutants including carbon dioxide, carbon monoxide, unburned hydrocarbons, sulfur dioxide, and nitrogen oxides (Abdul-Wahab et al. 2019). A study using life cycle analysis (LCA) shows adverse environmental impact associated with the production of photovoltaic modules when the electricity generated from the production is coming from conventional energy sources (Sagani, Mihelis and Dedoussis 2017). However, the use of PV technology further presents important environmental benefits compared to fossil fuel-powered electricity systems. The real option model proposed in this study may also be coupled with environmental analysis or LCA using the point of view of low- to middle-income consumers adopting solar PV.

Finally, we compare the economic attractiveness of own-use electricity from solar PV over continuing electricity from the grid. Future studies may also consider selling the excess electricity, using a hybrid energy system, incorporating energy storage, community energy sharing, and connection to the smart grid for additional revenue and optimize the value of investments (AbdulWahab, Mujezinovic and Al-Mahruqi 2019; Rodrigues et al 2020; Liang, Shirsat and Tang 2020; Bertolini, DÁlpaos and Moretto 2018; McKenna, Pless and Darby 2018). Although there are some limitations, we believe that the ROA framework proposed in this study could be a good benchmark for further analysis of investment decisions for the adoption of cleaner and more sustainable sources of electricity in residential buildings.

\section{Conclusion}

In the next decades, own-use solar photovoltaic technologies in residential houses, commercial buildings, and industries are expected to bring significant changes in the energy transition from fossil fuel-based to low- or zerocarbon power systems. Several studies apply various approaches to evaluate an investment in solar projects including the traditional valuation methods, incorporating socio-political and environmental aspects of an investment, and the real options valuation. We contribute to the literature by proposing the real options framework that evaluates the advantage of adopting the own-use solar photovoltaic system in residential buildings over continuing electricity from the grid with a focus on the various investment strategies in the context of developing countries.

Applying the real options approach using the Philippines as a case study, we provide important insights on how various payment schemes and uncertainties affect the value of the project and the optimal timing of making investment decisions. With the full payment scheme, results obtain option values of USD 6888 for RB-I, USD 15349 for RB-II, USD 21204 for RB-III, USD 27870 for RBIV, and USD 34251 for RB-V which are decreasing with later investment. Contrary to previous studies applying the ROV with an optimal decision to defer investment, our findings suggest earlier adoption of solar PV as postponing investments incur additional cost and opportunity losses from paying electricity from the grid. On the other hand, the option values increase by $21.6 \%$ and $22.5 \%$ with a distributed payment scheme to a 5- or 10-year period. The values also increase by $5 \%$ for installment with a $40 \%$ down payment, $13 \%$ with a $20 \%$ down payment, and $22 \%$ without a down payment. These findings suggest that the most optimal investment scheme is paying the PV system cost for a 10-year period without a down payment. This investment strategy is particularly relevant to households 
from developing countries with low capacity to pay the PV system cost in full. We find that these results are robust with the sensitivity in electricity prices and all residential building types investigated. In addition to financial benefits, the adoption of solar PV contributes to GHG emission reduction from the decrease in consumption of fossil-based electricity; creates jobs solar PV market development; provides reliable and more stable grid supply particularly in rural areas; and other health and environmental benefits.

Given these findings, we recommend governments to support the adoption of own-use solar projects as these will reduce the burden of paying high electricity cost from the grid. On a larger scale, this will significantly contribute to addressing the problems of energy security and sustainability as well as reducing emissions from burning fossil fuels for electricity generation. The government support may include a subsidy for using cleaner technology or carbon tax for using electricity from fossil fuels. The government may also encourage private companies to invest in research and development to accelerate the maturity of solar technology which may eventually reduce its capital cost. Finally, we suggest the financial institutions to offer more affordable terms and condition of payment as this may encourage low to medium income households to adopt own-use solar.

Nomenclature
Symbol/Variable
$\boldsymbol{\alpha}$
$\boldsymbol{\sigma}$
$\delta$
$\rho$
$\boldsymbol{\tau}$
$\mathrm{dt}$
$\mathrm{dz}$
$\varepsilon$
$\mathrm{n}$
$\mathrm{t}$
$\mathrm{C}$
$\mathbb{E}[\mathrm{NPV}]$
$\mathrm{I}_{\boldsymbol{\tau}}$
$\mathrm{I}_{\mathrm{dp}}$
$\mathrm{I}_{\text {ins }}$
$\mathrm{J}$
$\mathrm{N}$
$\mathrm{NPV}_{\text {solar }}$
$\mathrm{OV}_{\mathrm{t}}$
$\mathrm{P}_{\text {elec }}$
$\mathrm{Q}$
$\mathrm{T}_{\mathrm{D}}$
$\mathrm{T}_{\text {solar }}$
$\mathrm{V}_{\mathrm{sav}}$

Abbreviations
ADF
DOE
FiT
GBM
IEA
IRENA
IRR
LCA
LCOE
Meralco
NPV
OV

Description

Drift of electricity prices

Volatility of electricity prices

Discount rate

Discount Factor

Optimal investment period

Infinitesimal time increment

Increment for Wiener process

Error term, uncertainty

Number of years for PV cost installment

Time, period

Cost of solar PV system

Expected Net Present Value

Full payment of solar PV cost

Initial down payment for solar PV

Monthly installment for solar PV

Number of repetitions for Monte Carlo

Normal distribution

NPV of solar PV investment

Electricity price

Annual electricity consumption

Decision making period

Lifetime of solar PV system

Energy saving value

\section{Meaning}

Augmented Dickey-Fuller

Department of Energy

Feed-in-Tariff

Geometric Brownian Motion

International Energy Agency

International Renewable Energy Agency

Internal Rate of Return

Life Cycle Analysis

Levelized Cost of Electricity

Manila Electric Company

Net Present Value

Option Values
Option Value

$\begin{array}{cl}\text { PBP } & \text { Payback Period } \\ \text { PI } & \text { Profitability Index } \\ \text { PV } & \text { Photovoltaic } \\ \text { RB } & \text { residential buildings } \\ \text { ROA } & \text { Real options approach } \\ \text { ROI } & \text { Return on Investments }\end{array}$

\section{Acknowledgments}

The authors acknowledge the support from Utrecht University and Mindoro State College of Agriculture and Technology. The authors are grateful for the valuable comments from International Conference on Applied Energy - Applied Energy Symposium on Low Carbon Cities and Urban Energy Systems 2019 to improve the paper.

\section{References}

Abensur, E. O., Moreira, D. F., \& de Faria, A. C. R. (2020). Geometric Brownian motion: an alternative to high-frequency trading for small investors. Independent Journal of Management \& Production, 11(3), 1434-1453. http://dx.doi.org/10.14807/ijmp.v11i3.1114

Abdul-Wahab, S., Charabi, Y., Al-Mahruqi, A. M., Osman, I., \& Osman, S. (2019). Selection of the best solar photovoltaic (PV) for Oman. Solar Energy, 188, 1156-1168. https://doi.org/10.1016/j.solener.2019.07.018

Abdul-Wahab, S., Mujezinovic, K., \& Al-Mahruqi, A. M. (2019). Optimal design and evaluation of a hybrid energy system for off-grid remote area. Energy Sources, Part A: Recovery, Utilization, and Environmental Effects, 1-13. https://doi.org/10.1080/15567036.2019.1656308

Adebayo, V., \& Koçyiğit, K. (2017) Techno-economic Analysis of an Off-grid Solar Photovoltaic Energy System for a Typical Rural Household in Adamawa State, Nigeria. https://www.researchgate.net/publication/319470224 Techno -economic_Analysis_of_an_Offgrid Solar Photovoltaic Energy System for a Typical Rur al_Household in_Adamawa_State_Nigeria

Agaton, C. B. (2018). Use coal or invest in renewables: a real options analysis of energy investments in the Philippines. Renewables: Wind, Water, and Solar, 5(1), 1-8. https://doi.org/10.1186/s40807-018-0047-2

Agaton, C. B., Collera, A. A., \& Guno, C. S. (2020). Socio-Economic and Environmental Analyses of Sustainable Public Transport in the Philippines. Sustainability, 12(11), 4720. https://doi.org/10.3390/su12114720

Agaton, C. B., \& Karl, H. (2018). A real options approach to renewable electricity generation in the Philippines. Energy, Sustainability and Society, 8(1), 1. https://doi.org/10.1186/s13705-017-0143-y

Agaton, C. B., Guno, C. S., Villanueva, R. O., \& Villanueva, R. O. (2019). Diesel or Electric Jeepney? A Case Study of Transport Investment in the Philippines Using the Real Options Approach. World Electric Vehicle Journal, 10(3), 51. https://doi.org/10.3390/wevj10030051

Agaton, C. B., Guno, C. S., Villanueva, R. O., \& Villanueva, R. O. (2020). Economic analysis of waste-to-energy investment in the Philippines: A real options approach. Applied Energy, 275, 115265. https://doi.org/10.1016/j.apenergy.2020.115265

Allouhi, A. (2020). Solar PV integration in commercial buildings for self-consumption based on life-cycle economic/environmental multi-objective optimization. Journal of Cleaner Production, 122375. https://doi.org/10.1016/j.jclepro.2020.122375 
Citation: Guno, C.S., Agaton, C.B., Villanueva, R.O. and Villanueva, R.O. (2021). Optimal Investment Strategy for Solar PV Integration in Residential Buildings: A Case Study in The Philippines. Int. Journal of Renewable Energy Development, 10(1),79-89, doi: 10.14710/ijred.2021.32657

$\mathrm{P}$ a g e $\mid 88$

Andreis, L., Flora, M., Fontini, F., \& Vargiolu, T. (2020). Pricing Reliability Options under different electricity price regimes. Energy Economics, 87, 104705. https://doi.org/10.1016/j.eneco.2020.104705

Bertolini, M., D'Alpaos, C., \& Moretto, M. (2018). Do Smart Grids boost investments in domestic PV plants? Evidence from the Italian electricity market. Energy, 149, 890-902. https://doi.org/10.1016/j.energy.2018.02.038

Borovkova, S., \& Schmeck, M. D. (2017). Electricity price modeling with stochastic time change. Energy Economics, 63, 51-65. https://doi.org/10.1016/j.eneco.2017.01.002

Cheng, C., Wang, Z., Liu, M., Chen, Q., Gbatu, A. P., \& Ren, X. (2017). Defer option valuation and optimal investment timing of solar photovoltaic projects under different electricity market systems and support schemes. Energy, 127, 594-610. https://doi.org/10.1016/j.energy.2017.03.157

D'Adamo, I. (2018). The profitability of residential photovoltaic systems. A new scheme of subsidies based on the price of $\mathrm{CO} 2$ in a developed PV market. Social Sciences, 7(9), 148. https://doi.org/10.3390/socsci7090148

D’Adamo, I., Falcone, P. M., Gastaldi, M., \& Morone, P. (2020). The economic viability of photovoltaic systems in public buildings: Evidence from Italy. Energy, 207, 118316. https://doi.org/10.1016/j.energy.2020.118316

De Schepper, E., Van Passel, S., \& Lizin, S. (2015). Economic benefits of combining clean energy technologies: the case of solar photovoltaics and battery electric vehicles. International journal of energy research, 39(8), 11091119. https://doi.org/10.1002/er.3315

Do, T. N., Burke, P. J., Baldwin, K. G., \& Nguyen, C. T. (2020). Underlying drivers and barriers for solar photovoltaics diffusion: The case of Vietnam. Energy Policy, 144, 111561. https://doi.org/10.1016/j.enpol.2020.111561

DOE (Department of Energy) 2019. Philippine Power Statistics. https://www.doe.gov.ph/sites/default/files/pdf/energy statisti cs/2019 power statistic 01 summary.pdf Accessed 20 March 2020.

Ellabban, O., \& Alassi, A. (2019). Integrated Economic Adoption Model for residential grid-connected photovoltaic systems: An Australian case study. Energy Reports, 5, 310-326. https://doi.org/10.1016/j.egyr.2019.02.004

Enteria, N., Awbi, H., \& Yoshino, H. (2015). Application of renewable energy sources and new building technologies for the Philippine single family detached house. International Journal of Energy and Environmental Engineering, 6(3), 267294. https://doi.org/10.1007/s40095-015-0174-0

Gahrooei, M. R., Zhang, Y., Ashuri, B., \& Augenbroe, G. (2016). Timing residential photovoltaic investments in the presence of demand uncertainties. Sustainable Cities and Society, 20, 109-123. https://doi.org/10.1016/j.scs.2015.10.003

Gazheli, A., \& van den Bergh, J. (2018). Real options analysis of investment in solar vs. wind energy: Diversification strategies under uncertain prices and costs. Renewable and Sustainable Energy Reviews, 82, 2693-2704. https://doi.org/10.1016/j.rser.2017.09.096

GIZ (Deutsche Gesellschaft für Internationale Zusammenarbeit $\mathrm{GmbH}$ ) 2013. "It's more sun in the Philippines. Available from https://www.doe.gov.ph/sites/default/files/pdf/netmeter/policy -brief-its-more-sun-in-the-philippines-V3.pdf

Guta, D. D. (2018). Determinants of household adoption of solar energy technology in rural Ethiopia. Journal of Cleaner Production, 204, 193-204. https://doi.org/10.1016/j.jclepro.2018.09.016

Hagerman, S., Jaramillo, P., \& Morgan, M. G. (2016). Is rooftop solar PV at socket parity without subsidies?. Energy Policy, 89, 84-94. https://doi.org/10.1016/j.enpol.2015.11.017

IEA (International Energy Agency) 2019. Renewables 2019: Market analysis and forecast from 2019 to 2024. https://www.iea.org/reports/renewables-2019 Accessed on 12 Aug 2020

IEA (International Energy Agency) 2020. Tracking Buildings. https://www.iea.org/reports/tracking-buildings-2020 Accessed on 27 July 2020
Ioannou, A., Angus, A., \& Brennan, F. (2018). Effect of electricity market price uncertainty modelling on the profitability assessment of offshore wind energy through an integrated lifecycle techno-economic model. J Physics: Conference Series, 1102(1), $012027 . \quad$ https://doi.org/10.1088/1742$\underline{6596 / 1102 / 1 / 012027}$

IRENA (International Renewable Energy Agency) 2017. Renewables Readiness Assessment: The Philippines. https://www.irena.org/publications/2017/Mar/RenewablesReadiness-Assessment-The-Philippines Accessed on 12 Aug 2020

Jäger-Waldau, A., Kougias, I., Taylor, N., \& Thiel, C. (2020). How photovoltaics can contribute to GHG emission reductions of $55 \%$ in the EU by 2030. Renewable and Sustainable Energy Reviews, 126 ,

109836. https://doi.org/10.1016/j.rser.2020.109836

Kabir, E., Kim, K. H., \& Szulejko, J. E. (2017). Social impacts of solar home systems in rural areas: A case study in Bangladesh. $\quad$ Energies, $10(10), \quad 1615$. https://doi.org/10.3390/en10101615

Kavlak, G., McNerney, J., \& Trancik, J. E. (2018). Evaluating the causes of cost reduction in photovoltaic modules. Energy policy, 123, https://doi.org/10.1016/j.enpol.2018.08.015

Khan, T., Khanam, S. N., Rahman, M. H., \& Rahman, S. M. (2019). Determinants of microfinance facility for installing solar home system (SHS) in rural Bangladesh. Energy Policy, 132, https://doi.org/10.1016/j.enpol.2019.05.047

Krungkaew, S., Kingphadung, K., Kwonpongsagoon, S., \& Mahayothee, B. (2020). Costs and benefits of using parabolic greenhouse solar dryers for dried herb products in Thailand. International Journal of GEOMATE, 18(67), 96-101. https://doi.org/10.21660/2020.67.5798

Liang, J., Shirsat, A., \& Tang, W. (2020). Sustainable communitybased PV-storage planning using the Nash bargaining solution. International Journal of Electrical Power \& Energy Systems, 118, https://doi.org/10.1016/j.ijepes.2019.105759

Lin, B., \& Chen, Y. (2019). Does electricity price matter for innovation in renewable energy technologies in China? Energy Economics, 78, 259-266. https://doi.org/10.1016/j.eneco.2018.11.014

Matsuo, T. (2019). Fostering grid-connected solar energy in emerging markets: The role of learning spillovers. Energy Research \& Social Science, 57, 101227. https://doi.org/10.1016/j.erss.2019.101227

McKenna, E., Pless, J., \& Darby, S. J. (2018). Solar photovoltaic self-consumption in the UK residential sector: New estimates from a smart grid demonstration project. Energy Policy, 118, 482-491. https://doi.org/10.1016/j.enpol.2018.04.006

Mehta, P., Griego, D., Nunez-Jimenez, A., \& Schlueter, A. (2019). The Impact of self-consumption regulation on individual and community solar PV adoption in Switzerland: an agent-based model. In Journal of Physics: Conference Series (Vol. 1343, No. 1, p. 012143). IOP Publishing. https://doi.org/10.1088/1742-6596/1343/1/012143

Moon, Y., \& Baran, M. (2018). Economic analysis of a residential PV system from the timing perspective: A real option model. Renewable energy, 125, 783-795. https://doi.org/10.1016/j.renene.2018.02.138

Nemet, G. F., Lu, J., Rai, V., \& Rao, R. (2020). Knowledge spillovers between PV installers can reduce the cost of installing solar PV. Energy Policy, 144, 111600. https://doi.org/10.1016/j.enpol.2020.111600

O'Shaughnessy, E., Cutler, D., Ardani, K., \& Margolis, R. (2018). Solar plus: A review of the end-user economics of solar PV integration with storage and load control in residential buildings. Applied energy, 228, 2165-2175. https://doi.org/10.1016/j.apenergy.2018.07.048

Palm, J. (2018). Household installation of solar panels-Motives and barriers in a 10-year perspective. Energy Policy, 113, 1-8. https://doi.org/10.1016/j.enpol.2017.10.047 
Penizzotto, F., Pringles, R., \& Olsina, F. (2019). Real options valuation of photovoltaic power investments in existing buildings. Renewable and Sustainable Energy Reviews, 114, 109308. https://doi.org/10.1016/j.rser.2019.109308

Pode, R. (2013). Financing LED solar home systems in developing countries. Renewable and Sustainable Energy Reviews, 25, 596-629. https://doi.org/10.1016/j.rser.2013.04.004

Purohit, I., Purohit, P., \& Shekhar, S. (2013). Evaluating the potential of concentrating solar power generation in Northwestern India. Energy policy, 62, 157-175. https://doi.org/10.1016/j.enpol.2013.06.069

Ren, M., Mitchell, C. R., \& Mo, W. (2020). Dynamic life cycle economic and environmental assessment of residential solar photovoltaic systems. Science of The Total Environment, 137932. https://doi.org/10.1016/j.scitotenv.2020.137932

Rodrigues, D. L., Ye, X., Xia, X., \& Zhu, B. (2020). Battery energy storage sizing optimisation for different ownership structures in a peer-to-peer energy sharing community. Applied Energy, 262,

114498. https://doi.org/10.1016/j.apenergy.2020.114498

Rodrigues, S., Chen, X., \& Morgado-Dias, F. J. E. P. (2017). Economic analysis of photovoltaic systems for the residential market under China's new regulation. Energy Policy, 101, 467-472. https://doi.org/10.1016/j.enpol.2016.10.039

Sagani, A., Mihelis, J., \& Dedoussis, V. (2017). Techno-economic analysis and life-cycle environmental impacts of small-scale building-integrated PV systems in Greece. Energy and Buildings, 139,

$277-290$ https://doi.org/10.1016/j.enbuild.2017.01.022

Schiel, C., Glöser-Chahoud, S., \& Schultmann, F. (2019). A real option application for emission control measures. Journal of Business Economics, 89(3), 291-325. https://doi.org/10.1007/s11573-018-0913-9

Spertino, F., Chicco, G., Ciocia, A., Corgnati, S., Di Leo, P., \& Raimondo, D. (2015, June). Electricity consumption assessment and PV system integration in grid-connected office buildings. In 2015 IEEE 15th International Conference on Environment and Electrical Engineering (EEEIC) (pp. 255-260).

IEEE. https://doi.org/10.1109/EEEIC.2015.7165548

Stankuniene, G., Streimikiene, D., \& Kyriakopoulos, G. L. (2020). Systematic Literature Review on Behavioral Barriers of Climate Change Mitigation in Households. Sustainability, 12(18), 7369. https://doi.org/10.3390/su12187369

Streimikiene, D., Lekavičius, V., Baležentis, T., Kyriakopoulos, G. L., \& Abrhám, J. (2020). Climate Change Mitigation Policies Targeting Households and Addressing Energy Poverty in European Union. Energies, 13(13), 3389. https://doi.org/10.3390/en13133389

Stoyanov, L., Zarkov, Z., Notton, G., \& Lazarov, V. (2020). Design Opportunities and Building Integration of PV systems.
In Energy Efficient Building Design (pp. 21-40). Springer, Cham. https://doi.org/10.1007/978-3-030-40671-4_2

Tantisattayakul, T., \& Kanchanapiya, P. (2017). Financial measures for promoting residential rooftop photovoltaics under a feed-in tariff framework in Thailand. Energy policy, 109, https://doi.org/10.1016/j.enpol.2017.06.061

260-269.

Tian, L., Pan, J., Du, R., Li, W., Zhen, Z., \& Qibing, G. (2017). The valuation of photovoltaic power generation under carbon market linkage based on real options. Applied energy, 201, 354-362. https://doi.org/10.1016/j.apenergy.2016.12.092

Torani, K., Rausser, G., \& Zilberman, D. (2016). Innovation subsidies versus consumer subsidies: A real options analysis of solar energy. Energy Policy, 92, 255-269. https://doi.org/10.1016/j.enpol.2015.07.010

Tracking Buildings. International Energy Agency, 2020. Available from: https://www.iea.org/reports/trackingbuildings- 2020

Trappey, A. J., Trappey, C. V., Tan, H., Liu, P. H., Li, S. J., \& Lin, L. C. (2016). The determinants of photovoltaic system costs: an evaluation using a hierarchical learning curve model. Journal of Cleaner Production, 112, 1709-1716. https://doi.org/10.1016/j.jclepro.2015.08.095

Yadav, P., Heynen, A. P., \& Palit, D. (2019). Pay-As-You-Go financing: A model for viable and widespread deployment of solar home systems in rural India. Energy for sustainable development, 48 , 139-153. https://doi.org/10.1016/j.esd.2018.12.005

Zeng, Y., \& Chen, W. (2020). The socially optimal energy storage incentives for microgrid: A real option game-theoretic approach. Science of The Total Environment, 710, 136199. https://doi.org/10.1016/j.scitotenv.2019.136199

Zhang, M. M., Zhou, P., \& Zhou, D. Q. (2016). A real options model for renewable energy investment with application to solar photovoltaic power generation in China. Energy Economics, 59, 213-226. https://doi.org/10.1016/i.eneco.2016.07.028

Zhang, M. M., Wang, Q., Zhou, D., \& Ding, H. (2019). Evaluating uncertain investment decisions in low-carbon transition toward renewable energy. Applied Energy, 240, 1049-1060. https://doi.org/10.1016/j.apenergy.2019.01.205

Zhang, X., Shen, J., Adkins, D., Yang, T., Tang, L., Zhao, X., ... \& Luo, H. (2015). The early design stage for building renovation with a novel loop-heat-pipe based solar thermal facade (LHPSTF) heat pump water heating system: Techno-economic analysis in three European climates. Energy Conversion and Management, 106, 964-986. https://doi.org/10.1016/j.enconman.2015.10.034 